\title{
Politeia and the Past in Xenophon and Isocrates*
}

\section{Carol Atack}

Both Xenophon and Isocrates use the past to analyse and comment on political problems of the present, and to provide authority for political programmes of the present and for the future, through connecting them to revered past figures and mythologies. For both, idealised versions of historical Greek communities provide a counterpoint to the disappointments and decline of present-day politics and politicians. Figures from the distant past become exemplars for political action in the present, and their achievements, and the political and social arrangements under which those achievements were completed, models for political reform. Xenophon and Isocrates draw on the wider Greek politeia tradition of writing about political and social customs, educational practices, and institutions, seen in both free-standing pamphlets, and sections embedded within longer historical, rhetorical and philosophical works. ${ }^{1}$ With the exception of Xenophon's Lacedaimoniōn Politeia, both Xenophon and Isocrates embed politeia elements in larger works.

Similarities in approach and argument between Isocrates and Xenophon have led many to treat them together as critics of Athenian democracy. ${ }^{2}$ Certainly both assert the exemplarity both of individuals and of politeiai, particularly in the form of the patrios politeia or "ancestral constitution". ${ }^{3}$ They share a didactic approach, in which they anticipate that readers can learn from these models of collective and individual excellence and even imitate them. Vincent Azoulay has identified this as evidence of a new direction in Greek political thought; Frances Pownall has shown its similarity to the didacticism of fourth-century historiography. ${ }^{4}$ This chapter explores how both Xenophon and Isocrates manipulate civic foundation myths and the politeia form to produce exemplary models for political reform, and consequently how they manipulate chronology and exploit the temporal ambiguities of the distant past to create stable exemplars to contrast with the present. For each, an imaginary version of the past provides an ideal political environment, the imitation of which might provide restoration from decline;

\footnotetext{
* This chapter draws on my postgraduate research at the University of Cambridge, funded by the Arts and Humanities Research Council, and my current research for the Anachronism and Antiquity project at the Faculty of Classics, University of Oxford, funded by the Leverhulme Trust. Thanks also to Tim Rood and Paul Cartledge for comments on this chapter.

${ }^{1}$ Bordes 1982 remains the most detailed survey of Greek politeia writing.

${ }^{2}$ Gray 2000; Ober 1998.

${ }^{3}$ See Atack 2010.

${ }^{4}$ Azoulay 2006; Pownall 2004.
} 
Xenophon may be more committed to these visions, and is more often treated as a utopian writer, while Isocrates' more knowing visions may be ironic or paradoxical. ${ }^{5}$ However, the location of their ideal politeiai in the past distinguishes their visions from those of modern utopian writers, who tend to place their utopias in the future. ${ }^{6}$ However, many aspects of their work, including the focus on ancient lawgivers and rulers, and their constitutions, have influenced what Gregory Claeys labels the "realist" tradition in utopian political writing, and through Plutarch's lives of lawgivers have had substantial influence on writers such as Rousseau. ${ }^{7}$

\section{The Funeral Speech and the Ancestral Constitution}

The manipulation of temporality is endemic within politeia writing, whether it takes the form of flattening out change to create an idealised past or present, or creating a revisionist history of the development of a politeia. ${ }^{8}$ While politeiai pamphlets rarely constituted an exhaustive survey of the political institutions or culture of a polis, some fourth-century texts take a largerscale view, or focus on political change. ${ }^{9}$ Jacqueline Bordes' focus is on the distinction between individual and collective as the subject of politeia writing. She treats the Aristotelian Constitution of the Athenians as an exceptional case, different from the main thrust of politeia writing, because of its separate historical narrative and survey of present institutions. ${ }^{10}$ This work organises Athenian history into a series of periods, summarised at the end of the historical survey, each of which is initiated by a significant change to the politeia; for example, change (metabolē) under Theseus led to "a slight deviation from monarchy" (Ath. Pol. 41.2). ${ }^{11}$ This list implies that the process of change is over, eliding the continual change and development that the restored democracy underwent between 403 and $323 \mathrm{BCE}$, and suggesting that the main features of this democracy, government by the masses through decrees and the courts, were fixed and unchanging.

\footnotetext{
${ }^{5}$ Blank 2013; Ferguson 1975, 54-60; Too 1995.

${ }^{6}$ See Goodwin and Taylor 1982, 21-28.

${ }^{7}$ Claeys 2011, 23; Manuel and Manuel 1979, 94-99. On Rousseau's use of ancient lawgivers in his Social Contract see I. E. Harvey 1995.

${ }^{8}$ Bordes 1982, 16-18; Ryffel 1949, 11-12. Plato's city-soul analogy, and linkage of constitution and characters, in the Republic, shows that this distinction is not entirely stable.

${ }^{9}$ The Oxyrhynchus Historian's brief description of the workings of the Boeotian constitution (Hell. Oxy. 11.2-4) is also descriptive rather than normative: Bruce 1967, 157-164; Moore 1975, 125-134.

10 Bordes 1982, 433-454; Hose 2002.

${ }^{11}$ Although the selection of material may constitute an argument. See Rhodes 1993; Toye 1999.
} 
However, treating the Aristotelian work as a more central example of politeia writing is helpful in illuminating the exploration of political change and the manipulation of the past in Xenophon and Isocrates' politeia writing. In their works, individuals and events are repositioned in qualitative time, political institutions of the present or desired for the future are anachronistically situated in the distant past. The temporal framework that Bordes treats as incidental to the politeia becomes more significant with these manipulations.

In surveying the past, the literary politeia tradition meshed with that other genre of public rhetoric that drew on an idealised past, the epitaphios logos (funeral speech). ${ }^{12}$ Funeral speeches typically had a linear temporal structure, starting with the important, albeit mythical, deeds of the early Athenians, which were then used in comparison with more recent Athenian history and the most recent war deaths commemorated in the speech. ${ }^{13}$ The funeral speech attributed to Lysias (believed to date from the 390s BCE, and, like Isocrates' works, not necessarily itself a delivered speech but a rhetorical exercise) obeys this structure, outlining the "great deeds" (Lys. 2.3-16), and then describing the parallel historical deeds of the Athenians in defending the Greeks at Marathon and Salamis (2.20-43); passing over the defeat of the Peloponnesian War (2.58-60), it assimilates those commemorated now to past Athenians: ${ }^{14}$

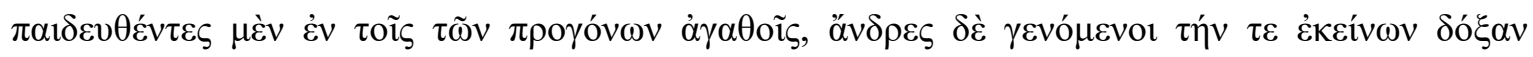

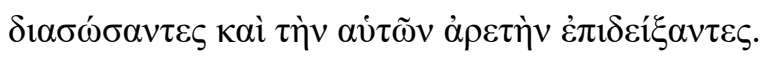

for they were first trained in the excellences of their ancestors, and then in manhood they preserved that ancient fame intact and displayed their own prowess (Lys. 2.69, translated Lamb).

For Athenians, the Marathon generation, who had both resisted Persian invasion (on behalf of all Greeks, echoing the mythical great deeds) and consolidated the democratic constitutional reforms of Cleisthenes (within Athens), provided an obvious group for democrats to idealise. But those opposed to the practices of democracy began to look further back, to the constitution attributed to Solon and beyond. ${ }^{15}$ General reverence for the past, and for the specific deeds of a recent generation, developed into specific claims about Athens' historical past, that were in

\footnotetext{
${ }^{12}$ Loraux 1986, 64-67, 88-89. Loraux notes the structural symmetries of the Athenian deeds, involving both barbarians (Amazons, Thracians, Persians) and Greeks (Thebes, Sparta, the Peloponnesian War). Loraux draws on Cornelius Castoriadis' model of the "political imaginary", as well as the broader psychoanalytic concept, to explore the funeral speech's relationship with democratic ideology: Castoriadis 1983; see also Adams 2014; Castoriadis 1997.

${ }^{13}$ Loraux 1986, 60-72.

${ }^{14}$ Loraux 1986, 42-56; Todd 2007, 149-153.

${ }^{15}$ Mossé 1979.
} 
turn incorporated into the developmental account of its democracy. The work of Xenophon and Isocrates displays some developments in this thinking, particularly a shift from collective to individual responsibility for the development of the Athenian politeia. ${ }^{16}$

Although Athenian mythology appears to be fundamental to the funeral speech, literary versions might omit it for effect, drawing attention to the temporal divide. Thucydides' version of a funeral oration, delivered by Pericles, omits the ancient deeds included in the Lysianic speech entirely, and focuses on the present (Th. 2.37.2). In Herodotus too, when his Athenians at Plataea debate the Tegeans (Hdt. 9.27.1-28.1) and list the heroic deeds of their ancestors (including their role in the Trojan War), they insist, in opposition to the Tegean who has invited

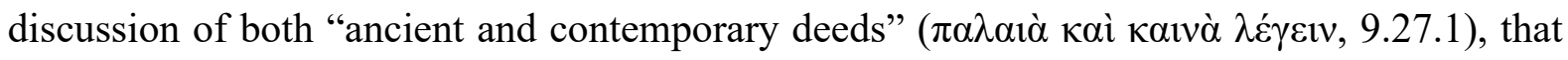
they deserve precedence on the basis of their recent achievements, not their past (9.27.5). These speeches suggest a conscious manipulation of both rhetorical tradition and differentiation of the past by the historiographers. Isocrates also engages with this practice, suggesting that he has avoided the use of "mythical" stories ( $\tau$ ov̀ $\varsigma \mu v \theta \dot{\delta} \delta \varepsilon 1 \zeta, 12.1$ ), while at the same time using it to contrast with or replace recent history. ${ }^{17}$

The assertion of continuing values sought to dampen remaining cultural and political conflict over Athenian identity, a conflict evident from dramatic sources. The debate between the two arguments in Aristophanes' Clouds, one representing the past and the other the present, is an example of this, as is the debate between Euripides and Aeschylus in the Frogs. The latter, staged in 405 BCE between the two oligarchic coups, encapsulates aspects of the ancestral constitution argument in presenting an authentic past form of Athenian culture as an alternative to a diminished present one. As the nature of Athenian democracy continued to be contested, the general appeal to the values of the past and the politeia text's imagining of that past began to merge into more specific "ancestral constitution" (patrios politeia) arguments. ${ }^{18}$

Finley argues that the desire to return to a past constitution is a feature of "sharp political conflict". ${ }^{19}$ This contestation is clear from surviving sources; the sophist Thrasymachus, discussing how politicians are unable to judge the distinction between opposing views, claimed that "the ancestral constitution causes confusion for them" ( $\pi \rho \tilde{\omega} \tau o v \mu \grave{\varepsilon} v \dot{\eta}$

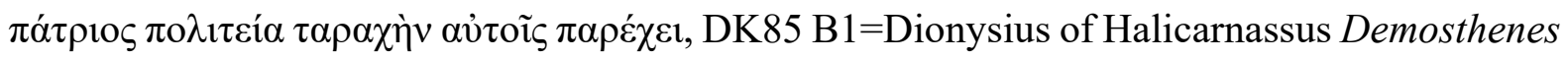

\footnotetext{
${ }^{16}$ Seen in Hyperides' epitaphios, in which the general Leosthenes is named and praised separately from the citizen soldiers (Loraux 1986, 111-112).

${ }^{17}$ Cf. Isoc. Evagoras 9.8, discussed below, and Marincola 2014; Welles 1966.

${ }^{18}$ Finley 1975; Fuks 1971; Ostwald 1986, 337-411.

${ }_{19}$ Finley 1975, 35, 40-42. Finley matches the Athenian example with the 17th-century CE English appeal to the Anglo-Saxon past, and to US affection for the founding fathers (Pocock 1987).
} 
3). The description patrios was ambiguous in its temporal scope, between present established custom learned from one's father, and a more distant past. Diodorus Siculus' account of the Spartan-mandated peace settlement of 403 BCE claims that both the democratic and oligarchic sides interpreted the concept differently. The democrats argued for "their fathers' constitution"

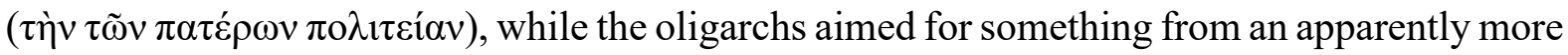

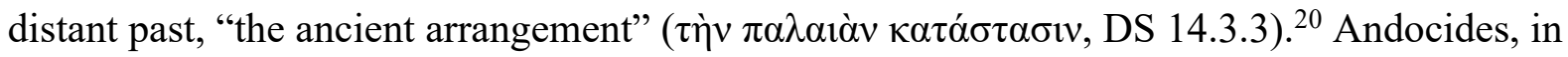
his self-defence against impiety charges, provides further evidence of the ambiguity of this term when he cites the decree of Teisamenos, also of 403 BCE. The Athenians agreed to ensure that, in the renewed democracy, Athens might be governed "according to ancestral custom" or

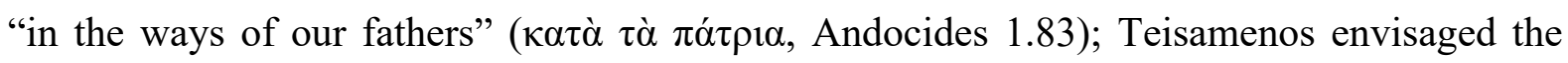
restoration of laws enacted by the early lawgivers Solon and Dracon as a means of achieving that, suggesting the more oligarchic reading. However, other writers used patrios to refer to religious tradition or civic custom currently in use, as Thucydides did in describing the practice of the public funeral speech as being $\tau \tilde{\omega} \pi \alpha \tau \rho i ́ \omega$ vó $\mu \omega$ (Thuc. 2.34.1). ${ }^{21}$

Xenophon invokes Athenian identity through the rhetoric of characters speaking during the political chaos and stasis of the final stages of the Peloponnesian War and its aftermath, notably the Eleusinian herald Cleocritus who asserts the shared religious and cultural experience of the Athenians (Xen. Hell. 2.4.20-22), and Thrasyboulos, who asserts that the

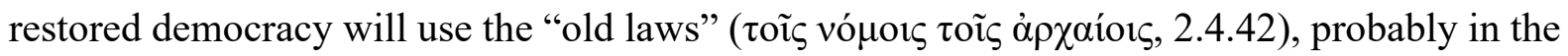
sense of the original or former laws, but still making a temporal contrast. ${ }^{22}$

Tensions between old and new aspects of constitutions, and manipulation of those histories of change, are a continuing feature of politeia writing seen in both Xenophon and Isocrates. This is not limited to discussing Athens, with its history of political change, but also appears in their writing on the Spartan politeia and on Persia and Egypt as counter-examples for Athens.

2. Narratives and Models of Development and Decline

\footnotetext{
20 The confused and apparently interpolated text in this part of the Aristotelian politeia reflects a similar debate (Ath. Pol. 29-33); Rhodes 1993.

${ }^{21}$ Lys. 1.30, 30.21, 30.29, 31.31; Finley 1975, 37; Walters 1976, 133-135. The two poles of this argument are represented by Ruschenbusch 1958 and Mossé 1978, cf. Rhodes 2011.

${ }^{22}$ Cf. Thuc. 8.76.6. Shear 2011 explores the context in which the restored democracy developed.
} 
Both Xenophon and Isocrates position their idealised politeiai in the past, creating structures in which past and present are thrown into sharp contrast by processes of change. ${ }^{23}$ The earlier, positive stage is the instantiation of political culture and practice in the polis, managed by a founder or law-giver. ${ }^{24}$ The later, negative stage is the degraded present, in which the original qualities of the politeia have been eroded by the weakness of the current citizens. Both Xenophon and Isocrates manipulate traditional accounts of the origins and development of constitutions by attributing later political practice to mythical founder figures, or even attributing practices to mythical figures located earlier in the chronology of the distant past than was traditional. In doing so, they use the politeia as a vehicle for claims of priority, significant in a culture which valued "first finder" status, and for establishing civic links to heroes and the divine.

Civic myths often featured multiple stages in a hazy chronology, as the history of Athens did from the foundation of its villages under Cecrops, synoecism under Theseus, and the end of kingship and development of laws under Dracon and Solon, or in the foundation and development of its democracy in more recent times. It is this multiplicity that makes Xenophon and Isocrates' manipulations possible, activities that fit Hans Blumenberg's model of continuing "work on myth", ${ }^{25}$ Political actors could be repositioned within these narratives, as the law-giver Solon appears to be in Herodotus' account of his meeting with Croesus (Hdt. 1.29-33), which stretches the limits of chronological possibility. ${ }^{26}$ Again, such accounts provide a model for manipulation or the reframing of an exemplum to serve a narrative or didactic purpose.

Isocrates' Panegyricus presents itself as a civic festival speech, at which praise of the city would be appropriate. ${ }^{27}$ But like all Isocrates' work the form functions as a dramatic device, and a means of critiquing democratic and public rhetoric, rather than representing its actual performance context. ${ }^{28} \mathrm{He}$ replicates multi-stage accounts of the development of Athens such as would later be seen in its local histories, introducing stories of Athenian autochthony (4.21-27), the connection of Demeter to Eleusis (4.28-33), and Athens' pioneering role in

\footnotetext{
${ }^{23}$ Constitutional change as an organising theme in Greek political thought is explored in Ryffel 1949.

${ }^{24}$ Lycurgus and Solon held both roles, according to Aristotle (Pol. 2.12.1273b32-34).

${ }^{25}$ Blumenberg 1985, cf. Bottici 2007, 20-43; Veyne 1988.

${ }^{26}$ Asheri 2007, 97-99.

${ }^{27}$ Loraux argues that this is an imaginary context (Loraux 1986, 89), while Buchner 1958 asserts the work's dependence on the Lysianic funeral speech.

${ }^{28}$ Isoc. 4.11-14. Pownall 2004, 25; Too 1995; on Isocrates' performative identity see Ober 1998, 257-260, 2004, 35-37, and on his prose style Usher 2010.
} 
developing the polis and protecting other communities (4.34-40). On the one hand, these stories are valuable evidence:

But how many good things we have contributed to the rest of the world we could estimate to best advantage if we should recount the history of our city from the beginning and go through all her achievements in detail; for we should find that not only was she the leader in the hazards of war, but that the social order in general in which we dwell, with which we share the rights of citizenship and

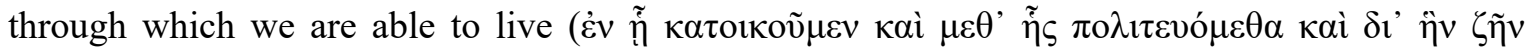
$\delta v v \alpha ́ \mu \varepsilon \theta \alpha)$, is almost wholly due to her (4.26-27, translation Norlin).

On the other hand, knowledge of the mythical past is uncertain. The "antiquity of the story"

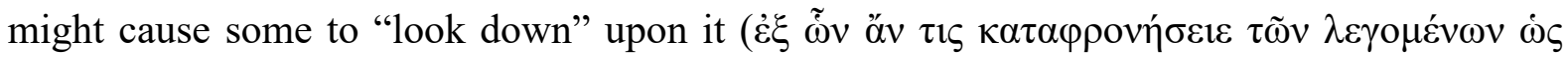

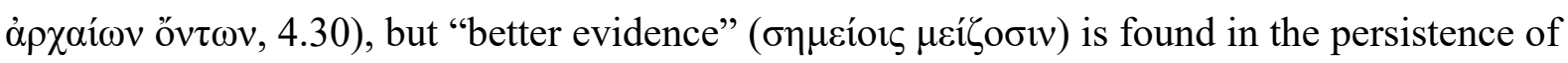
the stories and the religious practices they inspire. ${ }^{29}$ It is the present acknowledgement of Athens' status through the continuing dispatch of first-fruits to Eleusis that supports Isocrates' claim, rather than the myth itself.

However, Isocrates' praise for Athens does not stop at this boundary between a knowable and unknowable past, but continues into a period of which greater knowledge can

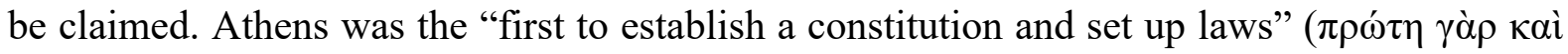

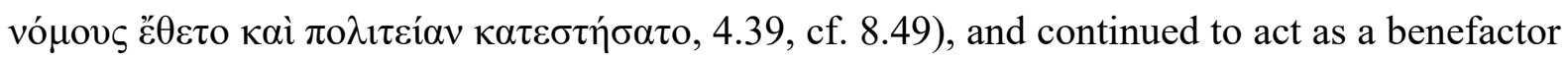
to the Greeks, offering safety and culture. ${ }^{30}$ Evidence for Athens' benefactions stretches to

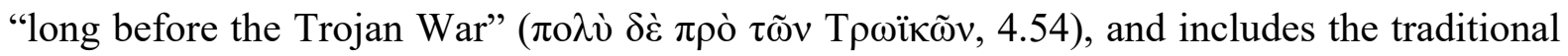
great deeds (4.56-70), here framed as the contribution of Athens' private resources to the public good of the Greeks. As with the Lysianic epitaphios, these past deeds lead on to more recent historical successes, notably those of the Marathon generation $(4.75,78-84)$, and are included with the more recent history and framed through it. ${ }^{31}$ The qualities of more recent Athenians provide evidence for the deeds of the earlier ones.

Like Xenophon on Sparta and Persia, Isocrates praises habits and practices rather than the specifics of legislation. Isocrates suggests that the great Athens of the past was based on unwritten laws guiding behaviour, rather than written rules and private contracts:

\footnotetext{
${ }^{29}$ Haskins 2005.

${ }^{30}$ Buchner 1958, 50-51.

31 The Panegyricus has a similar structure to the funeral speech in Plato's Menexenus, and the two have been fruitfully read together as a commentary of Athenian democratic self-mythology (Eucken 2010; Haskins 2005); both draw on the Lysianic epitaphios.
} 


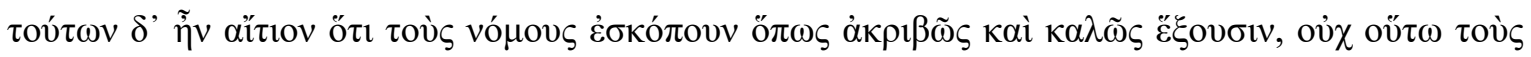

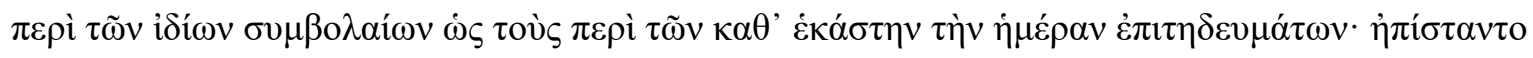

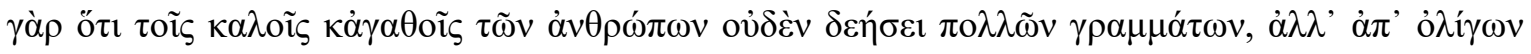

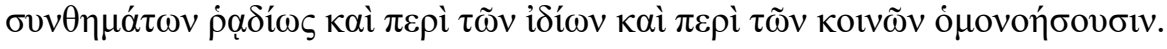

The reason for this was that they gave heed to the laws to see that they should be exact and goodnot so much the laws about private contracts as those which have to do with men's daily habits of life; for they understood that for good and true men there would be no need of many written laws, but that if they started with a few principles of agreement they would readily be of one mind as to both private and public affairs (4.78, tr. Norlin).

Because they are like-minded good men, these Athenians do not need positive written law.

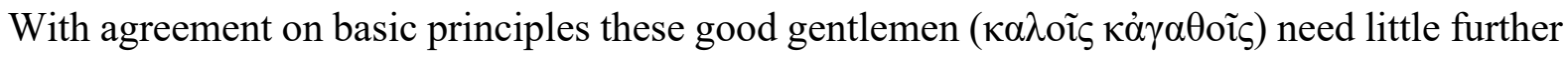
guidance whether in individual or communal action. ${ }^{32}$ Their actions are directed towards the public good, both within Athens and the wider Greek world (4.80-81). Again, this turns a key debating point in fourth-century political thought into a settled practice of the past. Plato's Eleatic Stranger suggests that written laws are required because of deficiencies in the citizens and their leaders (Pl. Plt. 294a-297b).$^{33}$ Developing the public/private divide that categorised Athenian deeds, Isocrates contrasts the unwritten laws that inform the Athenians' public

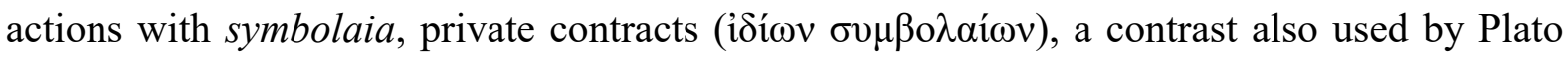
(Plt. 295a1).

Isocrates claims that the unwritten form of Athenian law meant that the ancestral constitution remained peculiar to its original city. Written laws can be copied easily (4.39), and were Athens' superiority based on its written laws, any polis could have copied them. Isocrates consistently treats the Athenian politeia as a source of inspiration for other cities, especially Sparta (which he here treats as a democracy, 4.61). His praise for the Athenian constitution sets him against other Athenian political theorists, who looked elsewhere for excellence as they criticised the development of Athenian democracy. ${ }^{34}$ While other commentators were praising the Spartan constitution (as Xenophon did, albeit with criticisms) or the Cretan constitution, Isocrates persisted in praising the Athenian ancestral constitution and arguing that it preceded

\footnotetext{
${ }^{32}$ Buchner 1958, 82-84.

33 El Murr 2014, 236-239; Gill 1995, cf. the contrast between nomoi and psēphismata, Aristotle Politics 4.4.1292a4-7.

${ }^{34}$ Ober 1998, 43-51.
} 
and inspired all others $(4.39,12.123-148)$. Plato's imaginary Athens is set in a deep version of the past (seen in his Timaeus/Critias), inaccessible to human knowledge owing to cyclical destruction, while Isocrates' is closer to hand, accessible to historical knowledge, and capable of being restored. ${ }^{35}$

By positioning political excellence in the past, Isocrates and Xenophon can criticise present political practice more easily. In their models of decline, present-day citizens no longer exemplify the virtues of their ancestors or the ideals of their established politeia. Preserving or restoring the customs of the past, gathered in the patrios politeia, offers a way to restore excellence and to prevent further decline, although Xenophon seems less confident that this can be achieved.

Isocrates' most detailed evocation of the Athenian ancestral constitution is in his Areopagiticus, where it is set against what he identifies as the present diminished way of life and political arrangements. ${ }^{36} \mathrm{He}$ notes that Athens has been subject to change (Isoc. 7.6), and declined further since the loss of its empire (7.8). Isocrates' claim is that the Athenians pay insufficient attention to the quality of their politeia, which is the "soul of the city" (7.14). This leads him to contrast the democracy "handed down to us by our forefathers" with the current version (7.15). Returning to this original democracy will, Isocrates claims, improve both the present and the future for the Athenians.

Isocrates describes a dual foundation of Athenian democracy, first under Solon and then Cleisthenes:

we should be willing to restore that earlier democracy which was instituted ( $\dot{\varepsilon} v 0 \mu 0 \theta \dot{\varepsilon} \tau \eta \sigma \varepsilon)$ by Solon, who proved himself above all others the friend of the people (o $\delta \eta \mu о \tau \kappa \kappa ं \tau \alpha \tau o \varsigma ~ \gamma \varepsilon v o ́ \mu \varepsilon v o \varsigma)$, and which was re-established by Cleisthenes, who drove out the tyrants and brought the people back into power (7.16, tr. Norlin).

He then goes on to describe the qualities of that politeia in contrast to those of the present. The heightened language matches each democratic keyword to a vice, associating the former with the past and the latter with the present:

For those who directed the state in the time of Solon and Cleisthenes did not establish a polity which in name merely was hailed as the most impartial and the mildest of governments, while in practice

\footnotetext{
35 See Morgan 2012.

${ }^{36}$ Loraux 1986, 218-219.
} 
showing itself the opposite to those who lived under it, nor one which trained the citizens in such fashion that they looked upon insolence as democracy, lawlessness as liberty, impudence of speech as equality, and licence to do what they pleased as happiness, but rather a polity which detested and punished such men and by so doing made all the citizens better and wiser (7.20).

But Isocrates has two specific points to make about why the ancestral constitution was preferable to present political practice. Firstly, he suggests that this democracy operated with a dual concept of equality that recognised differing worth among citizens and allocated honours accordingly (7.21). Secondly, the distribution of political office was carried out according to individual worth or merit, rather than by lot (7.22-23). The idea of such "geometric" or "proportionate" equality as ensuring fair distribution according to merit was central to fourthcentury political thought, explored in most detail in Aristotle's Nicomachean Ethics. ${ }^{37}$ The political consequences of lot versus election and selection were also much debated (Aristotle Politics, Plato Laws), and often placed on a developmental framework. In situating his preferred arrangements in an idealised past, Isocrates endows them with its authority.

Isocrates emphasises the encouragement of good habits rather than the administration of prescriptive laws (7.39-40). ${ }^{38}$ The Areopagus Council supervises moral discipline rather than administers positive law, making it seem akin to the Nocturnal Council of Plato's Magnesia; Isocrates is revising the view of how the ancestral constitution might be expressed. ${ }^{39}$ A set of practices that Plato will associate with the future is presented as present in the past. Isocrates here values custom and practice over decrees or instructions, as if the members of the Areopagus Council were a set of living preambles encouraging the citizens to better behaviour by providing them with a template for living well $(7.42,46)$. Under their encouragement, Athens flourished, as each citizen was directed into an appropriate occupation, and discouraged from wrong-doing by surveillance (7.47); this recalls the Socratic principle of specialisation, which has an anti-democratic effect in that citizens cannot excel in both wage-earning craft skills and political participation. ${ }^{40}$ The role and membership of the Areopagus Council had been changed through democratic reforms; made up of former archons, it embodied the change that lot selection had brought to a formerly aristocratic institution. ${ }^{41}$ The role of the Areopagus Council changed again during the fourth century, for example regaining some legal functions

\footnotetext{
${ }^{37}$ Arist. EN 5.5; see F.D. Harvey 1965, 1966.

${ }^{38}$ Isocrates anticipates that Athenians will fail to enforce legally prescribed penalties, 8.50.

${ }^{39}$ Mossé 1979; Rhodes 2006.

${ }^{40}$ Cf. Busiris 11.16-18; Pl. Resp. 2.374a4-d6, 4.433a8-b1; Xen. Cyr. 8.2.5-6.

41 Wallace 1989.
} 
in $344 \mathrm{BCE}$; the siting of the $338 / 7 \mathrm{BCE}$ anti-tyranny decree at its meeting-place suggests that some had concerns about members' commitment to democracy. ${ }^{42}$ Isocrates' vision of its role acknowledges both its history and the present anxieties about its possible role as a base for attempted regime change. ${ }^{43}$

For Xenophon, the position of the ideal politeia in the past is emphasised by descriptions of present citizens' failure to conform to its ideals (Lac. Pol. 14, Cyr. 8.8); both Sparta and Persia have fallen away from ancestral custom. The authorship of these sections has been challenged by some editors (notably Miller), although more recent commentators have seen these chapters as structurally integral to the works, demonstrating the sophistication of Xenophon's arguments. ${ }^{44}$

Xenophon's description of the origins of the Spartan constitution differs in detail from other accounts. He flattens the multi-stage developmental process described in other accounts (for example, Plato Laws 3.691d-692a) into a single event, by attributing all the arrangements described to the law-giver Lycurgus. He represents them as the deliberate pursuit of social arrangements different from those of other cities:

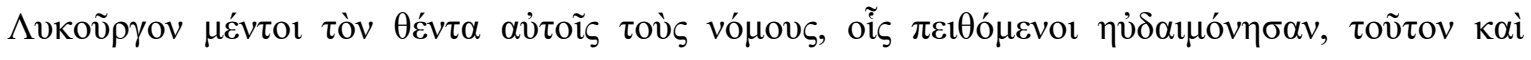

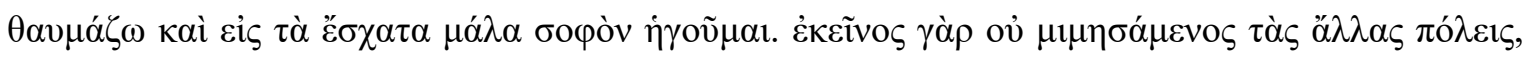

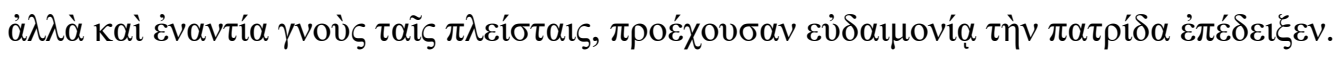

I stopped wondering once I had pondered the Spartiates' institutions, for they have achieved success by obeying the laws laid down for them by Lycurgus. I certainly admire him and consider him in the highest degree a wise man, since it was not by copying other states, but by deciding on an opposite course to the majority that he made his country outstandingly fortunate (Lac. Pol. 1.2, translation Marchant).

Xenophon's account is part of a competitive discourse that sets Athens apart from Sparta, in which Athens' internal critics used Sparta as an exemplum of an alternative political system and culture. While Xenophon seems at one level to be a straightforward partisan for Spartan excellence, his criticism of the brutality of Spartan leadership, of generals such as Clearchus

\footnotetext{
${ }^{42} R O 79=S E G$ xii 87; Solon may have instituted a similar law (Ath. Pol. 8.4), although this section of the work has been challenged, and Rhodes notes its Isocratean flavour (Rhodes 1993, 154-155).

${ }^{43}$ Ober 1998, 282-286.

${ }^{44}$ Gera 1993, 299-300; Gray 2011, 247; Miller 1914, 2.438-439.
} 
(Ana. 2.6.1-15) and Mnasippus (Hell. 6.2.5-23) in his narrative texts, suggests a more critical approach to Spartan culture than that displayed in his encomium of Agesilaus. ${ }^{45}$

Xenophon presents the Spartan constitution as an original settlement from which there had subsequently been a decline. His recognition of the contrast between past and present delimits the conditionality of Spartan excellence, making him a more subtle analyst than Ollier's characterisation of him as "le laconisant par excellence". ${ }^{46}$ Despite the excellent arrangements put in place by founder figures Lycurgus and Cyrus, the practices of current Spartans and Persians fail to attain the promised ideal, even though the institutions through which they could be delivered may still be in place. The Spartan constitution could no longer bear the claims made for its superiority; it no longer obeyed the laws of Lycurgus that had powered its distinctive political and military culture. For Xenophon, the failure lay with individuals rather than the system itself:

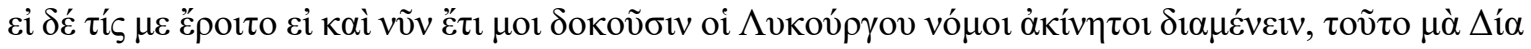

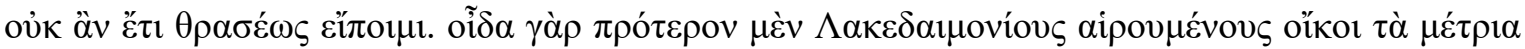

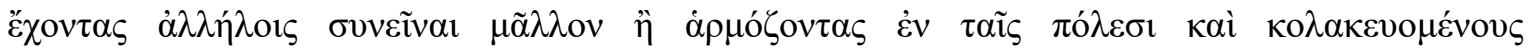
$\delta 1 \alpha \varphi \theta \varepsilon i ́ \rho \varepsilon \sigma \theta \alpha$.

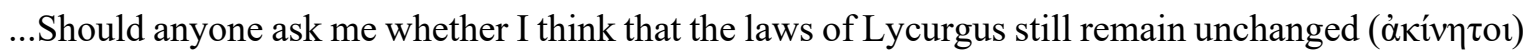

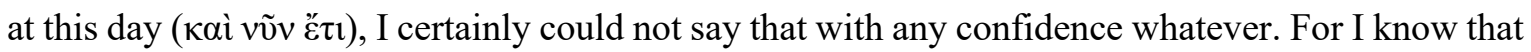
formerly the Lacedaemonians preferred to live together at home with moderate fortunes rather than expose themselves to the corrupting influences of flattery as governors of dependent states. (Lac. Pol. 14.1-2, translation Marchant)

The sharp distinction between past and present reframes the argument of the whole work, contrasting change with the stability of the past when Lycurgus' customs still were in force. Notably, corruption has come from outside rather than from within.

In the Cyropaedia, the evolution and decline of the Persian politeia are more complex. Xenophon carefully sets out the traditional Persian politeia, under which Cyrus is educated and develops his leadership skills, at the beginning of the work (Cyr. 1.2), emphasising its continuation into the present ("̌兀 $\tau$ Kaì võv, 1.2.1, 16). Xenophon's Persia somewhat resembles his Spartan politeia with its emphasis on training for endurance and war, but education for

\footnotetext{
${ }^{45}$ Hornblower 2000; Millender 2012.

${ }^{46}$ Ollier 1973, 373; Humble 2004, 220-222.
} 
citizenship and the administration of justice also feature. ${ }^{47}$ The merits of the Persian paideia are explored through anecdotes of Cyrus' education and through contrast with the despotic court of Cyrus' maternal grandfather Astyages, king of the Medes; Xenophon finds limits to the quality of justice in both. ${ }^{48}$

Xenophon identifies similar arrangements among Cyrus' campaign forces and in his new kingdom. Xenophon represents Cyrus' adoption of rewards based on merit for his troops as an innovation (Cyr. 2.3.2-16), put into practice in his campaign under the strict control of Cyrus (3.3.6-7). Throughout the Cyropaedia, Xenophon emphasises the past foundation of good practices, but distinguishes those that have continued unchanged since before Cyrus' time, from those which have been innovations of Cyrus and others, such as the transformation of the Persian elite into a cavalry force (4.2.3-23), or the injunction against lying (1.6.33), that have persisted into the present. ${ }^{49}$

As the narrative of the Cyropaedia progresses, Cyrus changes aspects of Persian practice, for example in switching the Persian elite into fighting as cavalry (Cyr. 4.2) and in instituting better organisation and training within military encampments, as well as the changing distribution of rewards discussed above. The success of these practices leads to Cyrus' victory, at which point he institutes a shift into a new mode of rule for his new empire, establishing himself as a king rather than a general (7.5.36); Xenophon accommodates both traditional Persian practices and Cyrus' reforms into his model. ${ }^{50}$ By rewriting the encounters of the defeated Croesus and victorious Cyrus (Hdt. 1.86.1-90, 206-8) as the recognition of Cyrus' skill as he transitions to his new form of leadership (Cyr. 7.2), Xenophon clearly positions Cyrus in a past that, like that of Solon and Cleisthenes, can generate ancestral good practice. $^{51}$

The distinctive perspective of the Cyropaedia's final chapter shows both continuity of institutions from the various developmental stages and a collapse in the values that supported them. After Cyrus' death, civil war between his sons provided opportunity for revolt, and "everything began to change for the worse" (8.8.2). Some of these changes relate to longstanding Persian customs, others to newer court practices instituted by Cyrus.

\footnotetext{
${ }^{47}$ Tuplin 1994.

48 Danzig 2009.

${ }^{49}$ Environmental factors are included; wild asses continue to breed (Cyr. 2.4.21).

50 Scholars distinguish the "republican" Persia from Cyrus' empire, but Xenophon does not treat Cyrus' innovations as the source of his empire's decline (Nadon 2001).

${ }^{51} \mathrm{Cf}$. Ellis 2016 on Xenophon's didactic purpose in retelling Herodotus' logos.
} 


\section{Repositioning the Ideal Past}

Another feature of Isocrates' and Xenophon's ancestral constitution arguments is that they relocate the idealised past further back into the past than its usual position in other versions of the ancestral constitution argument, from relatively recent historical times to a space on the boundary of historical and mythical time. The distinction between history and myth, as conceptualised by the Greeks, was in some senses both temporal and spatial, and in others dependent on the ontological status of the actors involved, as with Herodotus' distinction between Minos and Polycrates as holders of power at sea (Hdt. 3.122.2). ${ }^{52}$ Again, there has been much scholarly debate on the nature or even the existence of this distinction, often described as that between the spatium historicum and spatium mythicum or (by Pierre VidalNaquet) as that between divine time and human time. ${ }^{53}$ For fourth-century authors, the distinction is not one of absolute chronology, but a relative chronology in which the more distant past can only be known indistinctly, a factor that may be due to temporal distance but may have other causes. In the more recent past, gods and heroes are no longer present (although characters may be retrospectively heroised), and greater and more accurate knowledge of events enables them to be fitted more precisely into a linear chronology. ${ }^{54}$

Xenophon's Spartan constitution includes temporal innovation that repositions Lycurgus at the time of the return of the Heraclids. This was emerging as a key transitional point between kinds of past in Greek historiography; the children of Heracles return to the Peloponnese, with the help of the Athenians, and establish their cities. ${ }^{55}$ In placing Lycurgus in the time of the Heraclids, Xenophon brings him closer to the heroic past:

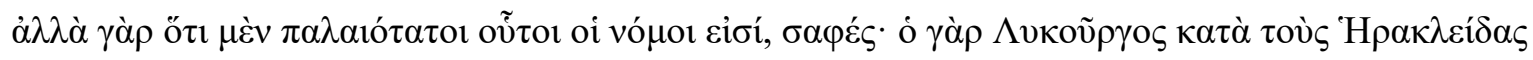

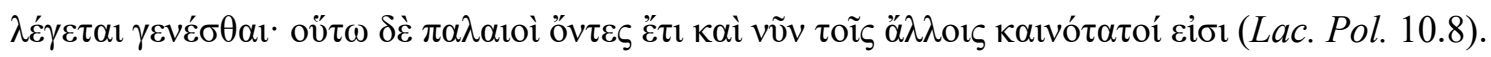

Now it is clear that these laws are of the greatest antiquity: for Lycurgus is said to have lived in the days of the Heracleidae. But although they are so ancient, even in the present day they are by comparison to others outstandingly novel (translation adapted from Marchant).

\footnotetext{
${ }^{52}$ Feeney 2007, 68, 77-82; Irwin 2007.

${ }^{53}$ Leyden 1949-50, 1963; Vidal-Naquet 1986, 40, cf. Vico 2002.

${ }^{54}$ On claims of accuracy, see Thuc. 1.22.2; Ephorus FGrH 70 F9.

55 Establishing a coherent relative chronology for Heracles, Theseus and the return of the Heraclids was a challenge to Athenian mythographers and dramatists.
} 
Xenophon's chronology differs from other sources, which place Lycurgus after the Heraclids and within historical time, although Herodotus simply places him in "an earlier time" (દ̌ $\tau$

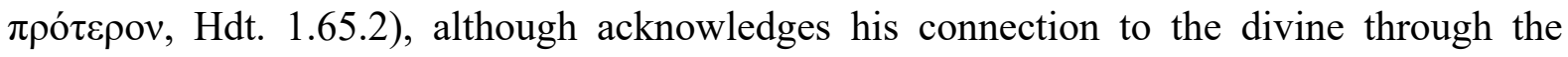
Delphic oracle's comments. Plato places Lycurgus' reforms as the second in a series of three changes in the Spartan constitution (P1. Leg. 3.691e1-692a3). However, the temporal location of Lycurgus was much disputed by ancient historians, perhaps unsurprisingly, given that so much was at stake in establishing the temporal priority of the first good constitution.

Establishing the temporal priority of the Spartan constitution makes it possible to challenge Isocrates' claim that it was merely an imitation of the Athenian politeia. Plutarch, surveying a range of contradictory sources, notes that the dates are disputed (Plutarch Lyc. 1.1), that there may have been more than one Lycurgus, and that Xenophon erred in failing to recognise that all Spartan kings are Heraclids (1.3). Xenophon's positioning emphasises the divine or heroic component in the Spartan constitution, gathering Lycurgus into the heroic tradition. It also enables Xenophon to claim temporal priority for the Spartan constitution, although he does not assert that point rather than establish its longevity within Sparta.

Xenophon expresses a paradox about the politeia; although these laws are the most

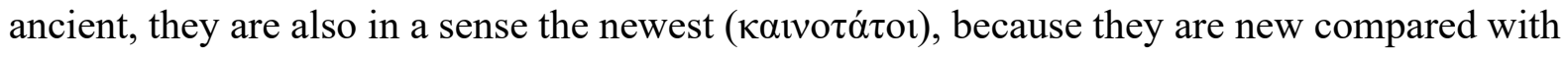
those of other constitutions, which have not adopted any similar policies. The rhetorical contrast of old and new, and between the recent and distant past, is also used by Isocrates in various contexts. ${ }^{56}$ In the Panegyricus itself, for example, Isocrates notes the importance of

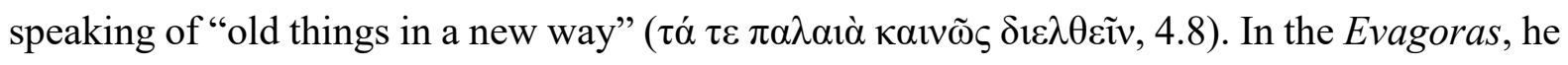
contrasts the present-day achievements of the eponymous king Evagoras of Salamis with the example of his ancestors back to the Homeric hero Ajax (9.5-6).

Xenophon's repositioning of Lycurgus jars because it appears to move him into a different kind of past. But Isocrates also repositions the Athenian patrios politeia in a similar way, providing it with heroic rather than human origins, and eventually replacing Solon the sage with Theseus the hero and king as originary figure. Isocrates began with an ideal version of Athens that drew on traditions of the Marathon generation (Panegyricus) and the Solonian constitution (Areopagiticus). The Panegyricus asserted the place of the great deeds within the historical rather than mythical past, unlike the myth of Demeter. While Xenophon repositions Lycurgus in time, Isocrates moves events further into the distant past by strengthening the

\footnotetext{
${ }^{56}$ D’Angour 2011.
} 
attribution of political change and the performance of the great deeds to Theseus. He represents the origin of Athenian democracy as linked to an even earlier moment of change in the Athenian constitution, the synoecism of the villages of Attica traditionally identified with the mythical king Theseus. ${ }^{57}$ This representation of the origins of the Athenian politeia appears in the Helen, and is modified in his final work, the Panathenaicus.

In the Helen, Isocrates tells the story of Theseus and Athens, as evidence of Helen's outstanding qualities in winning the admiration of a man of complete virtue (Helen 10.21-22). Theseus' claim to this status is based on his heroic deeds as an individual (10.25-29), his role in the great deeds of the Athenians (10.31), and his role in uniting Athens (10.35), and establishing its politeia (10.37). Notable is Theseus' role in the deeds; whereas the Lysianic speech attributes them to the Athenians collectively, Isocrates insists that receiving the supplications of Adrastus and the Heraclids was Theseus' own work:

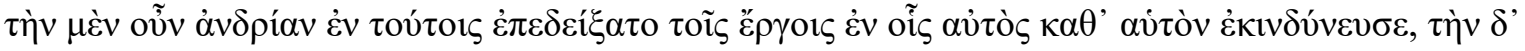

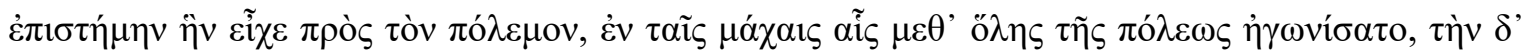

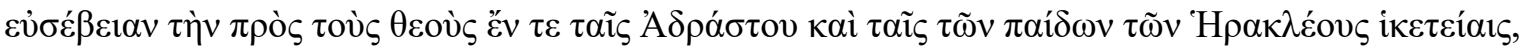

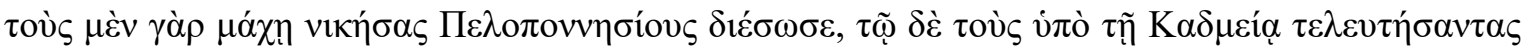

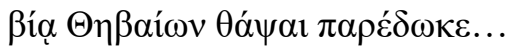

His courage Theseus displayed in these perilous exploits which he hazarded alone; his knowledge of war in the battles he fought in company with the whole city; his piety toward the gods in connexion with the supplications of Adrastus and the children of Heracles when, by defeating the Peloponnesians in battle, he saved the lives of the children, and to Adrastus he restored for burial, despite the Thebans, the bodies of those who had died beneath the walls of the Cadmea... (Helen 10.31, translation Van Hook)

The singular verbs emphasise the individual agency of Theseus, powered by his piety. Theseus continues as a sole actor in uniting the villages of Attica into a single city, in which citizens might compete for honour on equal terms (10.35); here Isocrates elaborates on the political act traditionally attributed to the king (cf. Th. 2.15.2). ${ }^{58}$

Isocrates goes on to describe a curious balance of power between king and citizens:

\footnotetext{
${ }^{57}$ Loraux 1986, 218-220; Theseus was celebrated in the Synoikia festival (Parker 2007, 480-481).

${ }^{58}$ Mitchell 2008.
} 


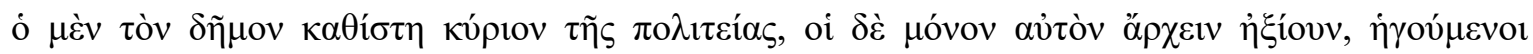

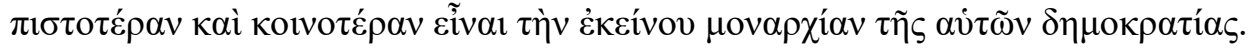

he made the people masters of the government, and they on their part thought it best that he should rule alone, believing that his sole rule was more to be trusted and more equitable than their democracy (Helen 10.36, translation Van Hook)

One function of this balance is that it suggests that the ancient Athenian constitution is a form of mixed constitution, a form of politeia valued by democracy's opponents and regarded as a source of stability. ${ }^{59}$ Another effect of Isocrates' changes is that this account of Athens' politeia moves the instantiation of the patrios politeia back towards the boundaries of myth and history, emphasising its heroic rather than its human origins. By emphasising the monarchic origins of Athenian democracy and placing them in the heroic past, Isocrates recognises a persistent strand in Athenian self-representation, the anachronistic figure of the democratic king. ${ }^{60}$ The incorporation of the myths of Athenian kings into the democratic city's account of itself was complex, but Athenians were familiar with tragedy's use of Theseus and other kings as mouthpieces for Athenian democratic ideology. By exploring Athens' mythical monarchical past, Isocrates is able to incorporate the figure of the virtuous monarch into Athenian history, and also to suggest new possible relationships between Athens and monarchical or autocratic states such as Macedon. ${ }^{61}$

Unlike the Lysian funeral speech, which praises the collective actions of the Athenian citizens, this version attributes the traditional strengths and even the deeds of the Athenian citizens to the king rather than to the collective citizenry. Isocrates anticipates or reflects trends in Athenian politics, in which more roles became the preserve of established experts, and praise for individual Athenians became more commonplace. ${ }^{62}$ The Athenian politician Lycurgus, himself an example of the changing pattern of Athenian democratic politics, uses stories of the Athenian kings to exemplify the virtue that a citizen should display. Codrus died to save his city (Lycurgus Leocrates 84-87), while Erechtheus sacrificed his daughter (Leocrates 98101). ${ }^{63}$ Lycurgus completes the link to tragic monarchy by quoting the speech Euripides gave to Erechtheus' queen as evidence of the virtue possessed by Athenian royalty. ${ }^{64}$

\footnotetext{
${ }^{59}$ Arist. Pol. 2.6.1265b26-33; Thuc. 8.97.2; Hahm 2009.

${ }^{60}$ Easterling 1985; Mills 1997

${ }^{61}$ Atack 2014, 343-354.

${ }^{62}$ Although the tradition of eisangelia prosecutions of generals suggests that blame was also apportioned more readily to individuals; Hansen 1975; see Humphreys 1985 for the career of Lycurgus.

${ }^{63}$ Erechtheus' sacrifice of his daughter is acceptable to both Euripides and Lycurgus because it is for the collective good of the city, unlike Agamemnon's sacrifice of Iphigeneia.

${ }^{64}$ Allen 2000; Steinbock 2011.
} 
While Xenophon's works predate the full flowering of this shift in Athenian political discourse, Isocrates' later works display it well. In the Panathenaicus Isocrates makes a further move to equate the relationship between Theseus and Athens to that between Philip of Macedon and the Greek world. He returns to the story of Theseus, finding a new angle to report, explicitly motivated by the desire not to return to a subject he has previously addressed (12.1267).

Isocrates also criticises others engaged with political thought by critiquing their grasp of the ancient past. Enthusiasts for the Spartan constitution receive some criticism (Panathenaicus) for their failure to understand its derivative qualities. But Isocrates does not limit his critique to the partisans of historical constitutions. ${ }^{65}$ His Busiris, which presents a constitution remarkably similar to that of Kallipolis as the patrios politeia of Egypt, put in place by its founder-king Busiris appears to be a critique of Plato's Republic. The Busiris is a complex and difficult text that participates in a sophistic tradition of paradoxical rhetoric. ${ }^{66}$ Some commentators have been reluctant to treat it as a work of serious political thought, but however serious its intent, the argumentative moves that Isocrates makes are consistent with those of more obviously political works, and are clearly aimed at Plato's political thought. Plato's imagined Kallipolis turns out, in the Busiris, to be a replica of the constitutional arrangements set in place by that king.

Isocrates' depiction of Busiris' Egypt emphasises its position in the distant past. The Egyptians live in a favourable climate that provides conditions similar to those of the golden age:

For in addition to the advantages I have mentioned, the Nile has bestowed upon the Egyptians a godlike (iøó $\theta \varepsilon \sigma v)$ power in respect to the cultivation of the land; for while Zeus is the dispenser of rains and droughts to the rest of mankind, each Egyptian has made himself master ( $\kappa$ ptos) of both of these on his own account (Busiris 11.13, translation Van Hook).

The antiquity of Egyptian culture and society compared with that of the Greeks was a longstanding topos of Greek thought, seen in Herodotus' account of Egypt, especially in the description of the genealogist Hecataeus' visit to Egypt (Hdt. 2.143), and replayed in Plato's account of Solon's visit to the temple of Neith/Athena that sets up his own account of primeval

\footnotetext{
${ }^{65}$ Aristotle divides constitutions into two categories, "historical" and "ideal", but his survey of examples in Politics 2 demonstrates that historical accounts of constitutions contained a great deal of idealisation, while ideal constitutions drew on historical sources: Lockwood 2015.

${ }^{66}$ Blank 2013; Livingstone 2001; Vasunia 2001.
} 
Athens before the flood (P1. Ti. 21b7-23b3). ${ }^{67}$ Isocrates appears to exploit this tradition to suggest that innovation in Plato's political thought is simply imitation of an existing constitution.

Isocrates presents Busiris as a skilled lawgiver who creates the Egyptian politeia. Just as Xenophon's account of Cyrus' forces reflects the programme of Athenian conservatives, Isocrates' description of Busiris' Egypt maps on to Plato's Kallipolis. There are fixed class divisions (11.15), and a principle of specialisation that requires that workers stick to their own techne (11.16-18). In this way both Busiris' Egypt and Kallipolis reflect the Solonian constitution.

Just as Xenophon praised Lycurgus' constitution for its resistance to change, Isocrates observes that those features which make the Egyptian constitution resistant to change have made it popular with philosophers and subject to imitation, notably by the Spartans (cf. Hdt. 2.80):

...also with respect to the system ( $\sigma 0 v v \tau \alpha \xi ı v)$ which enables them to preserve royalty and their political institutions in general, they have been so successful that philosophers who undertake to

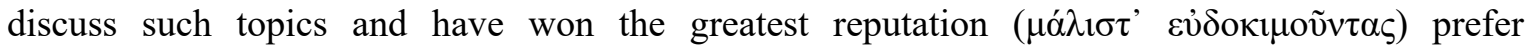
( $\pi \rho \circ \alpha \iota \varepsilon \tilde{\sigma} \sigma \alpha \iota)$ above all others the Egyptian form of government, and that the Lacedaemonians, on

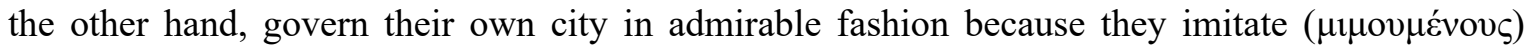
certain of the Egyptian customs (Busiris 11.17).

Xenophon's Persia and Isocrates' Egypt complicate the model of the ancestral constitution by removing it from the specifically Greek context of the polis. The arrangements of the Greek city are no longer the precondition for good administration and the preservation of community. Monarchical systems such as those of Cyrus and Busiris offer greater stability and better attention to such important matters as just distribution of assets. Both authors make similar claims in relation to more contemporary monarchic figures, Evagoras of the city of Salamis on Cyprus for Isocrates and Agesilaus of Sparta for Xenophon. In both these cases, the connection of the monarch with the mythical past supports their excellence; Xenophon explicitly links Agesilaus' excellence to his connection with the manners of the past, while Evagoras' excellence is established by comparing his deeds with those of his mythical ancestor.

\section{Relating Xenophon and Isocrates}

\footnotetext{
${ }^{67}$ On Plato’s use of Herodotus, see Desclos 2003 and Pradeau 1997.
} 
As this chapter has shown, Xenophon and Isocrates participate in the same debates, use similar material, and at times make similar argumentative moves, in evoking the patrios politeia. Whether there was any direct contact between them at any point is much less clear; Xenophon is not the only Laconophile whom Isocrates could have criticised. Isocrates alludes to the Ten Thousand when he needs to make the point that the Persian Army is weak and would be vulnerable to a Panhellenic expeditionary force (4.145). It is difficult to secure the composition dates for the texts of both authors in a way that could suggest any direct responses between them. Each has significant interests not reflected in the work of the other, from Xenophon's interest in the practical activities of the gentleman, hunting and estate management, to Isocrates' greater involvement in Athenian legal processes, represented by his early forensic speeches as well as the construction of his autobiographical account as a defence speech.

But in using the imagined past as a location for political excellence, and in further distancing the good politeia by locating it in the past, often of a distant place, Xenophon and Isocrates manipulate the accepted accounts of political development, and challenge the claims of present Athenian politicians and theorists, including those who are uncritical Laconophiles. They incorporate elements from rhetoric and historiography but adapt them to produce complex scenes of irretrievable utopia. 


\section{BIBLIOGRAPHY}

Abbreviations

DK Diels, H., Kranz, W. (1951), Die Fragmente Der Vorsokratiker: Griechisch Und Deutsch, Berlin.

FGrH Jacoby, F. (1923-58), Die Fragmente der griechischen Historiker, Berlin.

RO Rhodes, P. J., Osborne, R. (2003), Greek Historical Inscriptions: 404-323 BC, Oxford.

References

Adams, S. (ed.), (2014), Cornelius Castoriadis: Key Concepts, London.

Allen, D. S. (2000), "Changing the Authoritative Voice: Lycurgus' Against Leocrates", ClAnt $19(1), 5-33$.

Asheri, D. (2007), “Book I”, in: D. Asheri / A.B. Lloyd / A. Corcella (eds.), A Commentary on Herodotus Books I-IV, Oxford, 57-218.

Atack, C. (2010), “Ancestral Constitutions in Fourth-Century BCE Athenian Political Argument: Genre and Re-invention", MPhil dissertation (University of Cambridge).

Atack, C. (2014), 'The Discourse of Kingship in Classical Athenian Thought', Histos, 8, 329362.

http://research.ncl.ac.uk/histos/documents/2014A12AtackDiscourseofKingship.pdf.

Azoulay, V. (2006), “Isocrate, Xénophon ou le politique transfiguré”, REA 108, 133-53.

Blank, T. G. M. (2013), "Isocrates on Paradoxical Discourse: An analysis of Helen and Busiris", Rhetorica 31 (1), 1-33.

Blumenberg, H. (1985), Work on Myth, trans. R.M. Wallace, Cambridge, MA.

Bordes, J. (1982), Politeia dans la pensée grecque jusqu'à Aristote, Paris.

Bottici, C. (2007), A Philosophy of Political Myth, Cambridge.

Bruce, I.A.F. (1967), An Historical Commentary on the Hellenica Oxyrhynchia, Cambridge.

Buchner, E. (1958), Der Panegyrikos des Isokrates: eine historisch-philologische Untersuchung, Wiesbaden.

Castoriadis, C. (1983), L'institution imaginaire de la société, 5th edn., Paris.

Castoriadis, C. (1997), "The Greek and the Modern Political Imaginary", in: World in Fragments, trans. D. A. Curtis, Stanford, CA, 84-107.

Claeys, G. (2011), Searching for Utopia: the History of an Idea, London. 
D'Angour, A. (2011), The Greeks and the New: Novelty in Ancient Greek Imagination and Experience, Cambridge.

Danzig, G. (2009), “Big Boys And Little Boys: Justice And Law In Xenophon’s Cyropaedia And Memorabilia", Polis 26 (2), 271-295.

Desclos, M.-L. (2003), Aux marges des dialogues de Platon: essai d'histoire anthropologique de la philosophie ancienne, Grenoble.

Easterling, P. E. (1985), “Anachronism in Greek Tragedy”, JHS 105, 1-10.

El Murr, D. (2014), Savoir et gouverner: essai sur la science politique platonicienne, Paris.

Ellis, A. (2016), “A Socratic History: Theology in Xenophon's Rewriting of Herodotus' Croesus Logos", JHS 136, 73-91.

Eucken, C. (2010), "Der platonische Menexenos und der Panegyrikos des Isokrates", MH 67 (3), 131-145.

Feeney, D. C. (2007), Caesar's Calendar: Ancient Time and the Beginnings of History, Berkeley.

Ferguson, J. (1975), Utopias of the Classical World, London.

Finley, M. I. (1975), "The Ancestral Constitution”, in: Id., The Use and Abuse of History, London, 34-59.

Fuks, A. (1971), The Ancestral Constitution: Four Studies in Athenian Party Politics at the End of the Fifth Century B.C, Westport, Conn.

Gera, D. L. (1993), Xenophon's Cyropaedia: Style, Genre, and Literary Technique, Oxford.

Gill, C. (1995), "Rethinking Constitutionalism in Statesman 291-303”, in: C. J. Rowe (ed.), Reading the Statesman: Proceedings of the III Symposium Platonicum, Sankt Augustin, 292-305.

Goodwin, B., Taylor, K. (1982), The Politics of Utopia: a Study in Theory and Practice, London.

Gray, V. J. (2000), “Xenophon and Isocrates”, in: C. J. Rowe, M. Schofield et alii (eds.), The Cambridge History of Greek and Roman Political Thought, Cambridge, 142-54.

Gray, V. J. (2011), Xenophon's Mirror Of Princes: Reading the Reflections, Oxford.

Hahm, D.E. (2009), "The Mixed Constitution in Greek Thought", in: R. Balot (ed.), A Companion to Greek and Roman Political Thought, Malden, MA, 178-198.

Hansen, M. H. (1975), Eisangelia: The Sovereignty of the People's Court in Athens in the Fourth Century B.C. and the Impeachment of Generals and Politicians, Odense.

Harvey, F. D. (1965), “Two Kinds of Equality”, $C \& M 26,101-146$.

Harvey, F. D. (1966), “Corrigenda to C\&M XXVI 1965 101-146”, C\&M 27, 99-100. 
Harvey, I. E. (1995), “Exemplarity and the Origins of Legislation”, in: A. Gelley (ed.), Unruly Examples: on the Rhetoric of Exemplarity, Stanford, CA, 211-254.

Haskins, E. V. (2005), "Philosophy, Rhetoric, and Cultural Memory: Rereading Plato's Menexenus and Isocrates'Panegyricus", Rhetoric Society Quarterly 35 (1), 25-45.

Hornblower, S. (2000), "Sticks, Stones, and Spartans: the Sociology of Spartan Violence”, in: H. van Wees (ed.), War and Violence in Ancient Greece, Swansea, 57-82.

Hose, M. (ed.), (2002), Aristoteles: Die historischen Fragmente, Bd. 20. Fragmente ; T. 3, Berlin.

Humble, N. (2004), "The Author, Date and Purpose of Chapter 14 of the Lakedaimonion Politeia", in: C. J. Tuplin (ed.), Xenophon and His World: Papers from a Conference Held in Liverpool in July 1999, Stuttgart, 215-228.

Humphreys, S. (1985), "Lycurgus of Butadae. An Athenian Aristocrat", in: J. W. Eadie, J. Ober (eds.), The Craft of the Ancient Historian. Essays in honor of Chester G. Starr, Lanham, MD, 199-252.

Irwin, E. (2007), “The Politics of Precedence: First 'Historians' on First 'Thalassocrats”, in: R. Osborne (ed.), Debating the Athenian Cultural Revolution: Art, Literature, Philosophy, and Politics 430-380 BC, Cambridge, 188-223.

Lamb, W. R. M. (1930), Lysias, Cambridge, MA.

Leyden, W. von (1949-50), "Spatium Historicum: the Historical Past as Viewed by Hecataeus, Herodotus and Thucydides", Durham University Journal 11, 89-104.

Leyden, W. von (1963), "History and the Concept of Relative Time", History and Theory 2 (3), 263-285.

Livingstone, N. (2001), A Commentary on Isocrates' Busiris, Leiden.

Lockwood, T. C. (2015), "Politics II: Political Critique, Political Theorizing, Political Innovation”, in: T. C. Lockwood / T. Samaras (eds.), Aristotle's Politics: A Critical Guide, Cambridge, 64-83.

Loraux, N. (1986), The Invention of Athens: The Funeral Oration in the Classical City, trans. A. Sheridan, Cambridge, MA.

Manuel, F. E., Manuel, F. P. (1979), Utopian Thought in the Western World, Oxford.

Marchant, E. C. (1968), Xenophon: Scripta Minora, 2nd edn., Cambridge, MA.

Marincola, J. (2014), "Rethinking Isocrates and Historiography", in: G. Parmeggiani (ed.), Between Thucydides and Polybius: the Golden Age of Greek Historiography, Cambridge, MA, 39-61. 
Millender, E. (2012), “Xenophon's Crafting of the Anabasis”, in: F. Hobden / C. Tuplin (eds.), Xenophon: Ethical Principles and Historical Enquiry, Leiden, 377-425.

Miller, W. (1914) (ed.), Xenophon: Cyropaedia, Cambridge.

Mills, S. (1997), Theseus, Tragedy, and the Athenian Empire, Oxford.

Mitchell, L. G. (2008), “Thucydides and the Monarch in Democracy”, Polis 25 (1), 1-30.

Moore, J. M. (1975), Aristotle and Xenophon on Democracy and Oligarchy, London.

Morgan, K. A. (2012), "Plato and the Stability of History", in: J. Marincola, L. LlewellynJones, C. Maciver (eds.), Greek Notions of the Past in the Archaic and Classical Eras: History Without Historians, Edinburgh, 227-252.

Mossé, C. (1978), "Le thème de la Patrios Politeia dans la pensée grecque du IVème siècle", Eirene 16, 81-89.

Mossé, C. (1979), “Comment s'élabore un mythe politique: Solon, 'père fondateur' de la démocratie athénienne", Annales. Histoire, Sciences Sociales 34 (3), 425-437.

Nadon, C. (2001), Xenophon's Prince: Republic and Empire in the Cyropaedia, Berkeley, CA.

Norlin, G., Van Hook, L. R. (1928-45) Isocrates, 3 vols. Cambridge, MA.

Ober, J. (1998), Political Dissent in Democratic Athens: Intellectual Critics of Popular Rule, Princeton, NJ.

Ober, J. (2004), "I, Socrates...the performative audacity of Isocrates' Antidosis", in: T. Poulakos, D. J. Depew (eds.), Isocrates and Civic Education, Austin, TX, 21-43.

Ollier, F. (1973), Le mirage spartiate: étude sur l'idéalisation de Sparte dans l'antiquité grecque, New York.

Ostwald, M. (1986), From Popular Sovereignty to the Sovereignty of Law: Law, Society, and Politics in Fifth-Century Athens, Berkeley.

Parker, R. (2007), Polytheism and Society at Athens, Oxford.

Pocock, J.G.A. (1987), The Ancient Constitution and the Feudal Law: A Study of English Historical Thought in the Seventeenth Century, 2nd edn., Cambridge.

Pownall, F.S. (2004), Lessons from the Past: The Moral Use of History in Fourth-Century Prose, Ann Arbor.

Pradeau, J.-F. (1997), Le monde de la politique: sur le récit atlante de Platon, Timée (17-27) et Critias, Sankt Augustin.

Rhodes, P.J. (1993), A Commentary on the Aristotelian Athenaion Politeia, 2nd edn., Oxford. Rhodes, P. J. (2006), “The Reforms and Laws of Solon: an Optimistic View”, in: J. Blok, A. P. M. H. Lardinois (eds.), Solon of Athens: New Historical and Philological Approaches, Leiden, 248-260. 
Rhodes, P. J. (2011), “Appeals to the Past in Classical Athens”, in: G. Herman (ed.), Stability and Crisis in the Athenian Democracy, Stuttgart, 13-30.

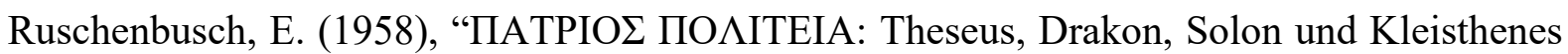
in Publizistik und Geschichts-schreibung des 5. und 4. Jahrhunderts v. Chr", Historia 7 (4), 398-424.

Ryffel, H. (1949), [Metabolē politeiōn] : Der Wandel der Staatsverfassungen, Bern.

Shear, J. L. (2011), Polis and Revolution: Responding to Oligarchy in Classical Athens, Cambridge.

Steinbock, B. (2011), “A Lesson in Patriotism: Lycurgus' Against Leocrates, the Ideology of the Ephebeia, and Athenian Social Memory", ClAnt 30 (2), 279-317.

Todd, S. C. (ed.), (2007), A Commentary on Lysias, Speeches 1-11, Oxford.

Too, Y. L. (1995), The Rhetoric of Identity in Isocrates: Text, Power, Pedagogy, Cambridge.

Toye, D. L. (1999), “Aristotle's Other Politeiai: Was the Athenaion Politeia Atypical?”, CJ 94 (3), 235-253.

Tuplin, C. J. (1994), "Xenophon, Sparta and the Cyropaedia", in: A. Powell / S. Hodkinson (eds.), The Shadow of Sparta, London, 127-164.

Usher, S. (2010), "Eurhythmia in Isocrates”, $C Q 60$ (1), 82-95.

Vasunia, P. (2001), The Gift of the Nile: Hellenizing Egypt from Aeschylus to Alexander, Berkeley, CA.

Veyne, P. (1988), Did the Greeks Believe in their Myths?, trans. P. Wissing, Chicago.

Vico, G. (2002), The First New Science, ed. L. Pompa, Cambridge.

Vidal-Naquet, P. (1986), The Black Hunter: Forms of Thought and Forms of Society in the Greek World, trans. A. Szegedy-Maszak, Baltimore, MD.

Wallace, R. W. (1989), The Areopagos Council, to 307 B.C, Baltimore.

Walters, K. R. (1976), “The 'Ancestral Constitution' and Fourth-century Historiography in Athens", AJAH 1, 129-144.

Welles, C. B. (1966), "Isocrates' View of History", in: L. Wallach (ed.), The Classical Tradition: Literary and Historical Studies in Honor of Harry Caplan, Ithaca, NY, 325. 